\title{
TITLE:
}

\section{Electrolytic Production of Silicon Using Liquid Zinc Alloy in Molten $\mathrm{CaCl} 2$}

\section{$\operatorname{AUTHOR}(S)$ :}

Yasuda, Kouji; Shimao, Takeyuki; Hagiwara, Rika; Homma, Takayuki; Nohira, Toshiyuki

\section{CITATION:}

Yasuda, Kouji ...[et al]. Electrolytic Production of Silicon Using Liquid Zinc Alloy in Molten CaCl2. Journal of The Electrochemical Society 2017, 164(8): H5049-H5056

\section{ISSUE DATE:}

2017-05-04

URL:

http://hdl.handle.net/2433/224952

\section{RIGHT:}

(c) The Author(s) 2017. Published by ECS. This is an open access article distributed under the terms of the Creative Commons Attribution 4.0 License (CC BY, http://creativecommons.org/licenses/by/4.0/), which permits unrestricted reuse of the work in any medium, provided the original work is properly cited. 


\title{
Electrolytic Production of Silicon Using Liquid Zinc Alloy in Molten $\mathrm{CaCl}_{2}$
}

\author{
Kouji Yasuda, ${ }^{\mathrm{a}, \mathrm{b}, *, \mathrm{z}}$ Takeyuki Shimao, ${ }^{\mathrm{a}}$ Rika Hagiwara, ${ }^{\mathrm{a}, *}$ Takayuki Homma, ${ }^{\mathrm{c}, *}$ \\ and Toshiyuki Nohira ${ }^{\mathbf{d}, *, \mathbf{z}}$ \\ ${ }^{a}$ Department of Fundamental Energy Science, Graduate School of Energy Science, Kyoto University, \\ Yoshida-honmachi, Sakyo-ku, Kyoto 606-8501, Japan \\ ${ }^{b}$ Agency for Health, Safety and Environment, Kyoto University, Yoshida-honmachi, Sakyo-ku, Kyoto 606-8501, Japan \\ ${ }^{c}$ Faculty of Science and Engineering, Waseda University, Shinjuku-ku, Tokyo 169-8555, Japan \\ ${ }^{d}$ Institute of Advanced Energy, Kyoto University, Gokasho, Uji 611-0011, Japan
}

\begin{abstract}
A new electrolytic production process for solar-grade Si has been proposed utilizing liquid $\mathrm{Si}-\mathrm{Zn}$ alloy cathode in $\mathrm{molten} \mathrm{CaCl}_{2}$. To establish this process, the behavior of liquid $\mathrm{Zn}$ metal in molten $\mathrm{CaCl}_{2}$ at $1123 \mathrm{~K}$ was investigated. Evaporation of $\mathrm{Zn}$ metal was largely suppressed by immersion in the molten salt, which enabled the use of a $\mathrm{Zn}$ electrode despite its high vapor pressure. Cyclic voltammetry results suggested that the reduction of $\mathrm{SiO}_{2}$ on a $\mathrm{Zn}$ cathode proceeded at a more negative than $1.45 \mathrm{~V}$ vs. $\mathrm{Ca}^{2+} / \mathrm{Ca}$. After potentiostatic electrolysis at $0.9 \mathrm{~V}$, Si particles with sizes of 2-30 $\mu \mathrm{m}$ were precipitated in the solidified $\mathrm{Zn}$ matrix by a slow cooling process. The rate-determining step for electrochemical reduction of $\mathrm{SiO}_{2}$ on the $\mathrm{Zn}$ cathode was discussed on the basis of a measurement of the alloying rate between solid $\mathrm{Si}$ and liquid $\mathrm{Zn}$.

(c) The Author(s) 2017. Published by ECS. This is an open access article distributed under the terms of the Creative Commons Attribution 4.0 License (CC BY, http://creativecommons.org/licenses/by/4.0/), which permits unrestricted reuse of the work in any medium, provided the original work is properly cited. [DOI: 10.1149/2.0121708jes] All rights reserved.

(cc) BY
\end{abstract}

Manuscript submitted January 18, 2017; revised manuscript received March 20, 2017. Published May 4, 2017. This was Paper 3440 presented at the Honolulu, Hawaii, Meeting of the Society, October 2-7, 2016. This paper is part of the JES Focus Issue on Progress in Molten Salts and Ionic Liquids.

Photovoltaic (PV) power generation has been developed as one of the key technologies that can mitigate the energy and environmental issues. Several national projects were launched in the 1970s such as the Sunshine Project of the Ministry of International Trade and Industry (MITI) in Japan and the Federal Photovoltaic Utilization Program of the Department of Energy (DOE) in the United States. Since then, the situation has changed dramatically, especially in the most recent decade, as demonstrated by the increased installation of PV cells promoted by political and financial support in various countries, the broadened use of technologies ranging from conventional electronic calculators and independent power sources to large-scale power stations, and the diversification of solar cell materials. Accordingly, the production volume of PV cells has increased in the 21 st century by a factor of more than 100; it was $285 \mathrm{MW}$ in 2000 and 36,100 MW in $2013 .{ }^{1}$ The percentage of the production volume contributed by compound-type solar cells such as the CdTe type and $\mathrm{Cu}-\mathrm{In}-\mathrm{Ga}-\mathrm{Se}$ (CIGS) type, which was only $0.4 \%$ in 2000 , increased to $7.6 \%$ in 2013. ${ }^{1}$

PV cell installation is expected to increase further in the future, as these cells represent a key technology for addressing environmental issues and providing diverse energy sources. In terms of solar cell materials, compound-type solar cells have drawbacks for mass production because the production capacities are limited by the supply of component materials obtained as byproducts in nonferrous metallurgy. For instance, the production capacity of CdTe solar cells is at most 6 to $8 \mathrm{GW}$ per year owing to the limited supply capacity of $\mathrm{Te}^{2}$ and that of CIGS solar cells is 20 to $30 \mathrm{GW}$ owing to the limited supply of Ga. Therefore, crystalline Si solar cells are most likely to be the main product of the PV industry in the long run.

High-purity $\mathrm{Si}$ used for crystalline $\mathrm{Si}$ solar cells is called solargrade $\mathrm{Si}(\mathrm{SOG}-\mathrm{Si}$ ), and its purity exceeds $5 \mathrm{~N}-7 \mathrm{~N}$. The Siemens process $^{3-6}$ using $\mathrm{H}_{2}$ reduction and/or thermal decomposition of trichlorosilane $\left(\mathrm{SiHCl}_{3}\right)$, which is currently used to produce SOG$\mathrm{Si}$, was originally developed to manufacture semiconductor-grade $\mathrm{Si}$ $(11 \mathrm{~N}-12 \mathrm{~N}$ purity) for large-scale integrated circuits (LSIs). Because of the slow reaction kinetics of silane gases, the Siemens process has inherent drawbacks of low productivity and low energy efficiency.

*Electrochemistry Society Member.

${ }^{\text {z} E-m a i l: ~ y a s u d a . k o u j i .3 v @ ~ k y o t o-u . a c . j p ; ~ n o h i r a . t o s h i y u k i .8 r @ k y o t o-u . a c . j p ~}$
To develop a next-generation production process for SOG-Si, various types of $\mathrm{Si}$ production or refining processes that can overcome the low productivity of the conventional Siemens process have been investigated, such as $\mathrm{H}_{2}$ reduction and/or decomposition of silanebased gases in improved Siemens-based processes, metallothermic reduction of silicon halides by metal reductants such as zinc and aluminum, and purification of metallurgical-grade Si (MG-Si; 98-99\% purity) using metallurgical purification methods. ${ }^{7,8}$ A refining process using the fluidized bed reaction of monosilane $\left(\mathrm{SiH}_{4}\right)$ at REC Silicon and SunEdison Samsung Fine Chemicals and upgrading of MG-Si (UMG) using various refining techniques have been operated recently on a mass production scale. ${ }^{9}$

Our group has studied direct electrolytic reduction of solid $\mathrm{SiO}_{2}$ to $\mathrm{Si}$ in molten $\mathrm{CaCl}_{2}$ at $1123 \mathrm{~K}$ as a new type of electrochemical process of $\mathrm{SiO}_{2}$ reduction. ${ }^{10-12}$ In this method, electrochemical reduction of insulating $\mathrm{SiO}_{2}$ is realized by using $\mathrm{a} \mathrm{SiO}_{2}$ contacting electrode, which provides a three-phase interface between the conductor, $\mathrm{SiO}_{2}$, and molten salt.

$$
\mathrm{SiO}_{2}(s)+4 \mathrm{e}^{-} \text {(through conductor) } \rightarrow \mathrm{Si}(s)+2 \mathrm{O}^{2-}
$$

We also proposed that a combination of electrolytic reduction of purified $\mathrm{SiO}_{2}$ and directional solidification refinement is a potential low-cost method of SOG-Si production. ${ }^{13-15}$ To improve the productivity of the process, we recently studied the electrochemical reduction of $\mathrm{SiO}_{2}$ granules set on a bottom cathode in molten $\mathrm{CaCl}_{2}$, analogous to the Hall-Héroult $\mathrm{Al}$ production process. ${ }^{16}$ Many research groups, including ours, have investigated direct electrochemical reduction of $\mathrm{SiO}_{2}$ for SOG-Si production. ${ }^{17-36}$ However, recovery of the powdery $\mathrm{Si}$ product from a mixture of $\mathrm{Si}, \mathrm{SiO}_{2}$, and $\mathrm{CaCl}_{2}$ is one of the challenges of using this method. Because separating the solid product from the molten salt is an inherent problem for molten salt processes, cathodic products are usually manufactured in the liquid state to facilitate their subsequent recovery in practical production processes of $\mathrm{Li}, \mathrm{Na}, \mathrm{Mg}$, and $\mathrm{Al}$ metals, and rare earth metals/alloys. Thus, we expected that using a liquid $\mathrm{Si}$ alloy cathode would be a solution for SOG-Si production in molten $\mathrm{CaCl}_{2}$.

A typical method of recovering a certain metal from a liquid alloy uses the principle of a solubility decrease with temperature reduction. A well-known industrial process, the imperial smelting process (ISP), is the simultaneous metallurgical production of $\mathrm{Zn}$ and $\mathrm{Pb}$. When a 
Table I. Properties of alloying elements for $\mathrm{Si}$.

\begin{tabular}{ccccc} 
Metal & $T_{\text {m.p. }} / \mathrm{K}$ & $T_{\text {b.p. }} / \mathrm{K}$ & Solubility of $\mathrm{Si}$ at $1123 \mathrm{~K} / \mathrm{mol} \%$ & Distribution coefficient between liquid and solid Si at $T_{\text {m.p. }}$ (Si) \\
\hline $\mathrm{Zn}$ & $693^{52}$ & $1180^{52}$ & $6.0^{54}$ & $1 \times 10^{-554}$ \\
$\mathrm{Sn}$ & $505^{53}$ & $2875^{53}$ & $0.9^{55}$ & $1.6 \times 10^{-255}$ \\
$\mathrm{~Pb}$ & $601^{52}$ & $2019^{52}$ & $<0.2^{56}$ & $2 \times 10^{-358}$ \\
$\mathrm{Al}$ & $933^{52}$ & $2791^{52}$ & $32.6^{57}$ & $2 \times 10^{-359}$
\end{tabular}

liquid $\mathrm{Si}$ alloy cathode is applied to electrolytic reduction of $\mathrm{SiO}_{2}$ in a molten salt, there are many advantages, such as easy separation of $\mathrm{Si}$ from both the molten salt and unreacted $\mathrm{SiO}_{2}$, and easy transfer from the electrolysis cell. Further, because MG-Si can be refined by solidification of liquid $\mathrm{Si}$ alloys, ${ }^{37-51}$ a high separation ability is expected in the precipitation of $\mathrm{Si}$ from a liquid alloy, in which impurities are removed from the solid phase.

As alloying elements for $\mathrm{Si}$ that give a liquid alloy, $\mathrm{Zn}, \mathrm{Sn}, \mathrm{Pb}$, and $\mathrm{Al}$ are candidates because they have no intermetallic compounds with Si. Their characteristics are summarized in Table I. ${ }^{52-59}$ Although Al shows promise because of its greater solubility at the electrolysis temperature, it is difficult to remove $\mathrm{Al}$ impurities from the $\mathrm{Si}$ phase. The minimum impurity level of $\mathrm{Al}$ is reported to be approximately $100 \mathrm{ppm}$ for electrolysis of $\mathrm{SiO}_{2}$ on an $\mathrm{Al}$ cathode ${ }^{31}$ and refining of low-purity $\mathrm{Si}$ using a $\mathrm{Si}-\mathrm{Al}$ alloy. ${ }^{37-41}$ Considering many factors, we selected $\mathrm{Zn}$ as the alloying element. For instance, the lower boiling point and smaller distribution coefficients are advantageous for obtaining high-purity $\mathrm{Si}$ products after vacuum refining and directional solidification in the final step.

Figure 1 schematically illustrates the proposed process for SOG$\mathrm{Si}$ production using a liquid $\mathrm{Si}-\mathrm{Zn}$ alloy cathode in molten salt. The overall process consists of three major processes: electrolysis, precipitation, and refining. In the electrolysis process, solid $\mathrm{SiO}_{2}$ is reduced to form a $\mathrm{Si}-\mathrm{Zn}$ liquid alloy at the cathode.

$$
\begin{aligned}
& \mathrm{SiO}_{2}(s)+\mathrm{Si}-\mathrm{Zn}(l, \text { low } \mathrm{Si} \text { conc. })+4 \mathrm{e}^{-} \rightarrow \mathrm{Si}-\mathrm{Zn} \\
& (l, \text { high } \mathrm{Si} \text { conc. })+2 \mathrm{O}^{2-}
\end{aligned}
$$

Figures $2 \mathrm{a}$ and $2 \mathrm{~b}$ show the entire range and $\mathrm{Zn}$-rich side of the phase diagram for the $\mathrm{Si}-\mathrm{Zn}$ system, respectively. ${ }^{54} \mathrm{Here}$, the changes in temperature and composition in the proposed process are indicated in Figure $2 \mathrm{~b}$ by arrows. The solubility of $\mathrm{Si}$ in liquid $\mathrm{Zn}$ is 6 at $\%$ at 1123 $\mathrm{K}$. The $\mathrm{Si}-\mathrm{Zn}$ liquid alloy produced at the bottom of the electrolysis cell is separated from the molten salt by density difference and is transferred to the precipitation process. In the precipitation process, metallic $\mathrm{Si}$ is recovered by lowering the temperature.

$$
\mathrm{Si}-\mathrm{Zn}(l, \text { high } \mathrm{Si} \text { conc. }) \rightarrow \mathrm{Si}(s)+\mathrm{Si}-\mathrm{Zn}(l, \text { low Si conc. })
$$

When the temperature is lowered to $923 \mathrm{~K}$, the solubility is also lowered to 1 at $\%-\mathrm{Si}$; thus, solid $\mathrm{Si}$ at 5 at $\%$ with reference to $\mathrm{Zn}$ is recovered. After the precipitation process, the $\mathrm{Si}-\mathrm{Zn}$ alloy with a low $\mathrm{Si}$ concentration is reused as the cathode in the electrolysis process. The produced $\mathrm{Si}$ is then transferred to the refining process. An ingot of SOG-Si is manufactured by directional solidification of the treated $\mathrm{Si}$ after leaching and vacuum refining.

This process is expected to have several advantages in terms of productivity and purification ability. In contrast to the Siemens process, the proposed process can be operated semicontinuously, which contributes to high productivity. High purification efficiency is expected because there are two segregation steps: precipitation of solid $\mathrm{Si}$ from the $\mathrm{Si}-\mathrm{Zn}$ liquid alloy in the precipitation process and precipitation of solid $\mathrm{Si}$ from liquid $\mathrm{Si}$ in the refining process. The low distribution coefficients of the impurity elements, which indicate high purification ability, are reported for precipitation from both liquids of metallic $\mathrm{Si}^{59}$ and alloys of $\mathrm{Si}-\mathrm{Al},{ }^{37-41} \mathrm{Si}-\mathrm{Cu},{ }^{42,43} \mathrm{Si}-$ $\mathrm{Sn},{ }^{44,46} \mathrm{Si}-\mathrm{Fe},{ }^{47-49} \mathrm{Si}-\mathrm{Ni},{ }^{50}$ and $\mathrm{Si}-\mathrm{Na} .{ }^{51}$ Furthermore, the remaining $\mathrm{Zn}$ can be easily removed to several parts per million even by the evacuation techniques used more than 30 years ago. ${ }^{60}$ More complete removal of $\mathrm{Zn}$ is possible by using advanced vacuum refining technology.

In this study, the fundamentals of the electrolysis process, namely, evaporation of $\mathrm{Zn}$ metal in molten $\mathrm{CaCl}_{2}$, electrochemical reduction of $\mathrm{SiO}_{2}$ on the $\mathrm{Zn}$ cathode, and the alloying rate for the $\mathrm{Si}-\mathrm{Zn}$ system, were investigated at $1123 \mathrm{~K}$. The effect of immersion of $\mathrm{Zn}$ metal in molten $\mathrm{CaCl}_{2}$ on its evaporation behavior was analyzed. Regarding the electrochemical behavior of the liquid $\mathrm{Zn}$ electrode, Kipouros and Sharma reported electrolysis of a $\mathrm{Ca}-\mathrm{Zn}$ liquid alloy in the molten $\mathrm{CaCl}_{2}-\mathrm{CaO}-\mathrm{CaF}_{2}$ system at $973-1023 \mathrm{~K}^{6}{ }^{61}$ However, the electrode potential was unclear because a two-electrode system was employed. In the present study, we investigated the effective potential range for

\section{Electrolysis}

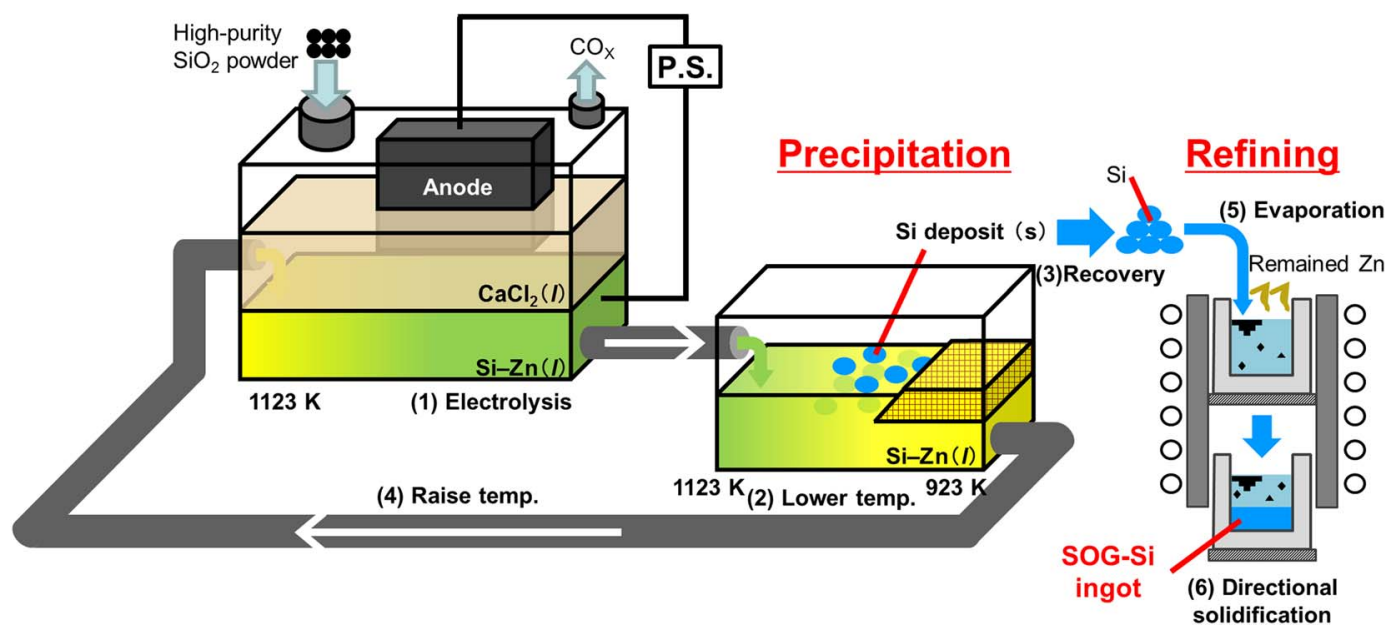

Figure 1. Schematic drawing of SOG-Si production using electrochemical reduction of $\mathrm{SiO}_{2}$ powder on a liquid $\mathrm{Si}-\mathrm{Zn}$ alloy cathode in molten $\mathrm{CaCl}$. 
(a)
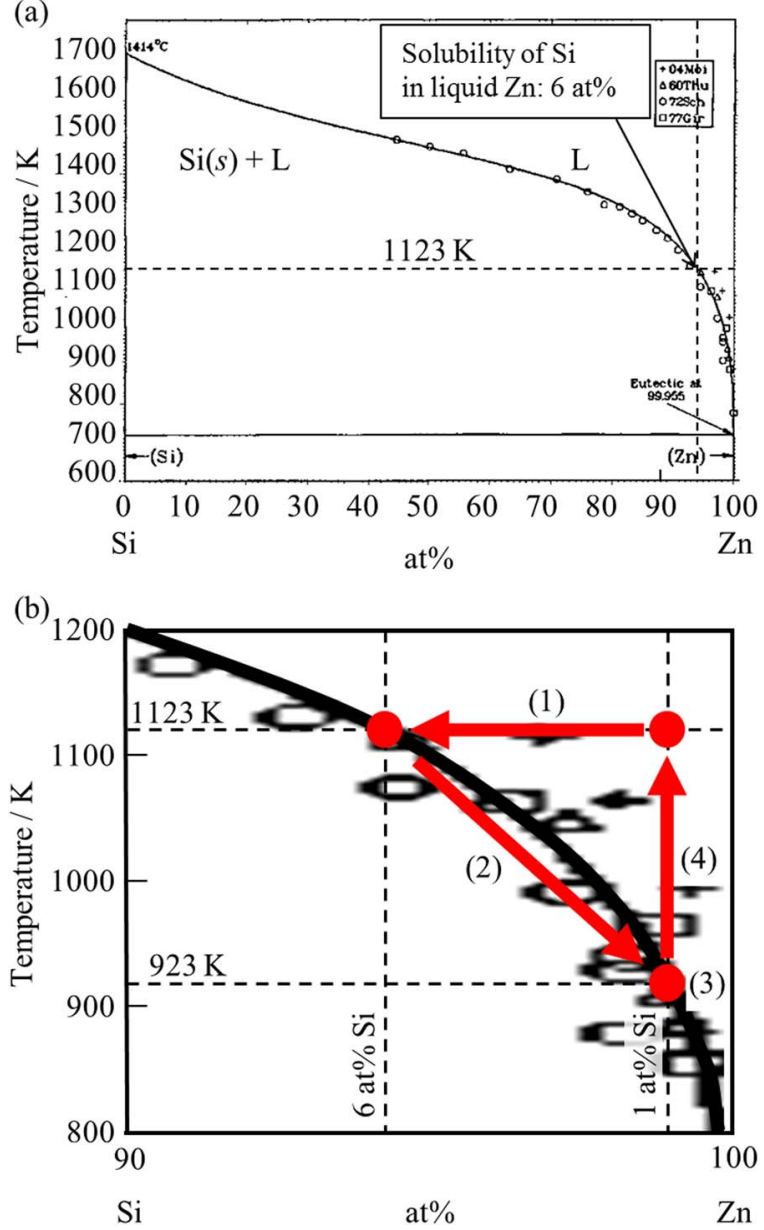

Figure 2. Binary phase diagram for the $\mathrm{Si}-\mathrm{Zn}$ system. ${ }^{54}$ (a) Entire composition range and (b) Zn-rich region.

the production of $\mathrm{Si}-\mathrm{Zn}$ alloy by electrolysis of $\mathrm{SiO}_{2}$ granules on the $\mathrm{Zn}$ electrode. Furthermore, the alloying rate was studied to estimate the rate-determining step in the electrochemical reaction on the $\mathrm{Zn}$ electrode.

\section{Experimental}

Evaporation of $\mathbf{Z n}$. - The evaporation rate of $\mathrm{Zn}$ in Ar atmosphere at $1123 \mathrm{~K}$ was measured using the weight change of $\mathrm{Zn}$ metal (Kojundo Chemical Laboratory Co., Ltd., 99.9999\%, grains, 5.4-5.6 g) placed at the bottom of a silica tube [outer diameter (o.d.) $12.5 \mathrm{~mm}$, inner diameter (i.d.) $10.5 \mathrm{~mm}$ ] with and without added $\mathrm{CaCl}_{2}$ (Kojundo Chemical Laboratory Co., Ltd., $>99 \%, 5.4-5.6$ g or $8.2-8.4 \mathrm{~g}$ ). The samples were dried under vacuum at $453 \mathrm{~K}$ for $24 \mathrm{~h}$ and charged in a silica tube in a glove bag under an Ar atmosphere. Then, a balloon was set on the open end of the tube with a paraffin film to maintain the Ar atmosphere. The tube was inserted into a silica chamber (i.d. $127 \mathrm{~mm}$, height $403 \mathrm{~mm}$ ) in an electric furnace maintained at 1123 $\mathrm{K}$ and was left for a given period of time. The tube was pulled out in $1 \mathrm{~min}$ and then cooled at room temperature. The $\mathrm{Zn}$ sample was weighed after water washing and drying. If separation of the $\mathrm{Zn}$ sample from the silica tube was difficult, its weight was calculated from the values before and after leaching treatment with $1 \mathrm{M} \mathrm{HCl}$ solutions. The $\mathrm{Zn}$ content in the molten salt was analyzed using inductively coupled plasma atomic emission spectrometry (ICP-AES; Thermo Scientific, iCAP 6200 Duo) of a solution prepared by dissolving 0.1 $\mathrm{g}$ of recovered $\mathrm{CaCl}_{2}$ into a $\mathrm{HNO}_{3}$ solution.

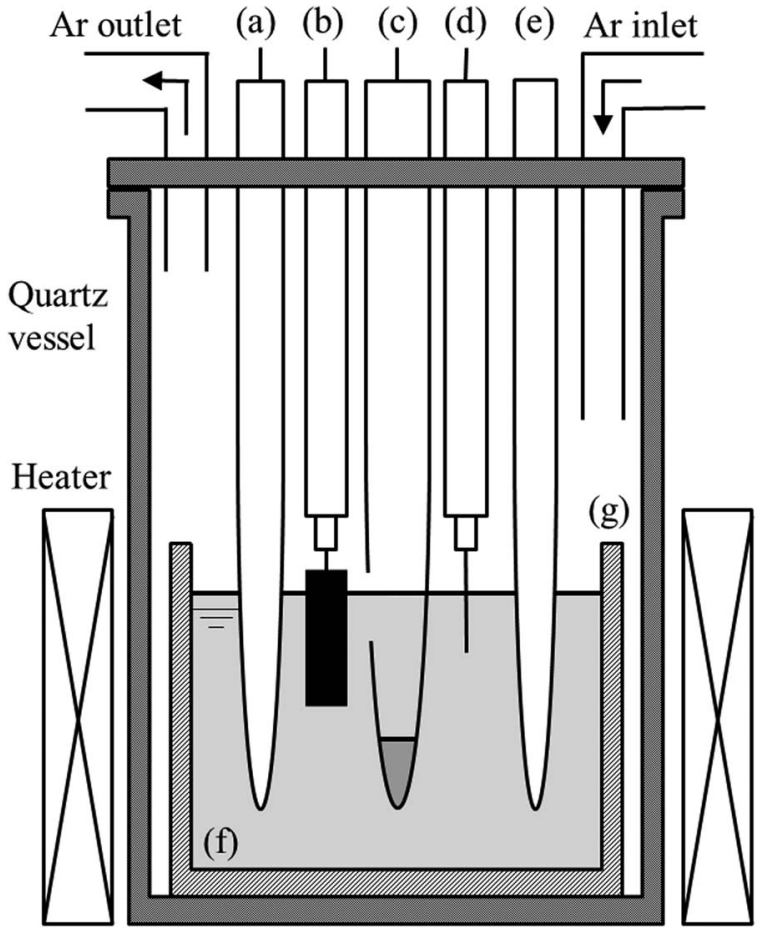

Figure 3. Schematic drawing of the electrolysis cell. (a) $\mathrm{Ag}^{+} / \mathrm{Ag}$ reference electrode, (b) graphite counter electrode, (c) liquid $\mathrm{Zn}$ electrode with $\mathrm{SiO}_{2}$ granules, (d) $\mathrm{Ca}^{2+} / \mathrm{Ca}$ dynamic reference electrode on a Mo wire, (e) thermocouple, (f) molten $\mathrm{CaCl}_{2}$, and (g) alumina crucible.

Electrochemical behavior.-Figure 3 schematically illustrates the electrochemical apparatus. $\mathrm{CaCl}_{2}(350 \mathrm{~g})$ was charged in an alumina crucible (Nikkato Corp., SSA-S grade, o.d. $87 \mathrm{~mm}$, i.d. $80 \mathrm{~mm}$, height $129 \mathrm{~mm}$ ) and dried under vacuum at 453 and $773 \mathrm{~K}$ for $24 \mathrm{~h}$ at each temperature. All the electrochemical experiments were performed in a dry Ar atmosphere at $1123 \mathrm{~K}$. The electrochemical behavior was investigated by cyclic voltammetry and potentiostatic electrolysis using a newly designed liquid $\mathrm{Zn}$ electrode. Figure 4 shows a photograph and a schematic illustration of the liquid $\mathrm{Zn}$ electrode. $\mathrm{Zn}$ grains (Kojundo Chemical Laboratory Co., Ltd., 99.9999\%, grains, 3-5 mm, $1.3 \mathrm{~g}$ ) were set at the bottom of an alumina tube (Nikkato Corp., (a)

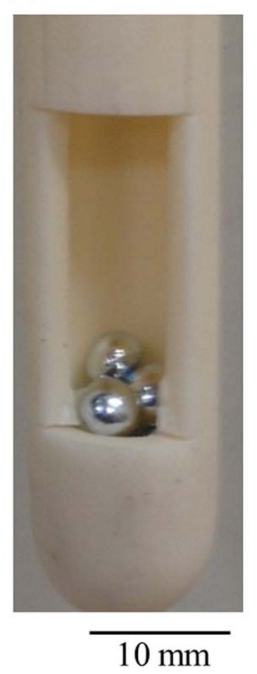

(b)

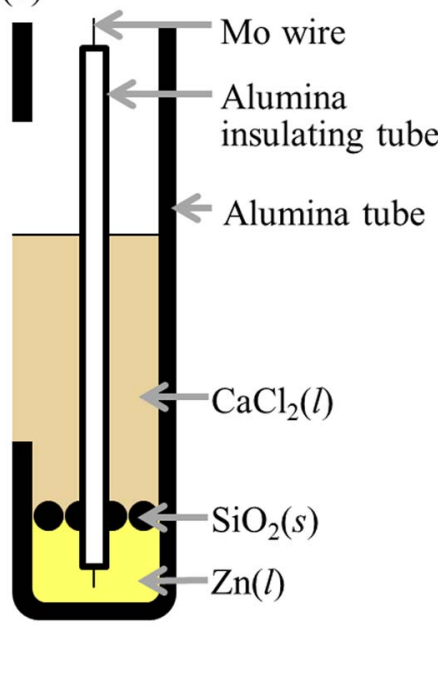

Figure 4. (a) Photograph and (b) schematic illustration of the Zn electrode. 


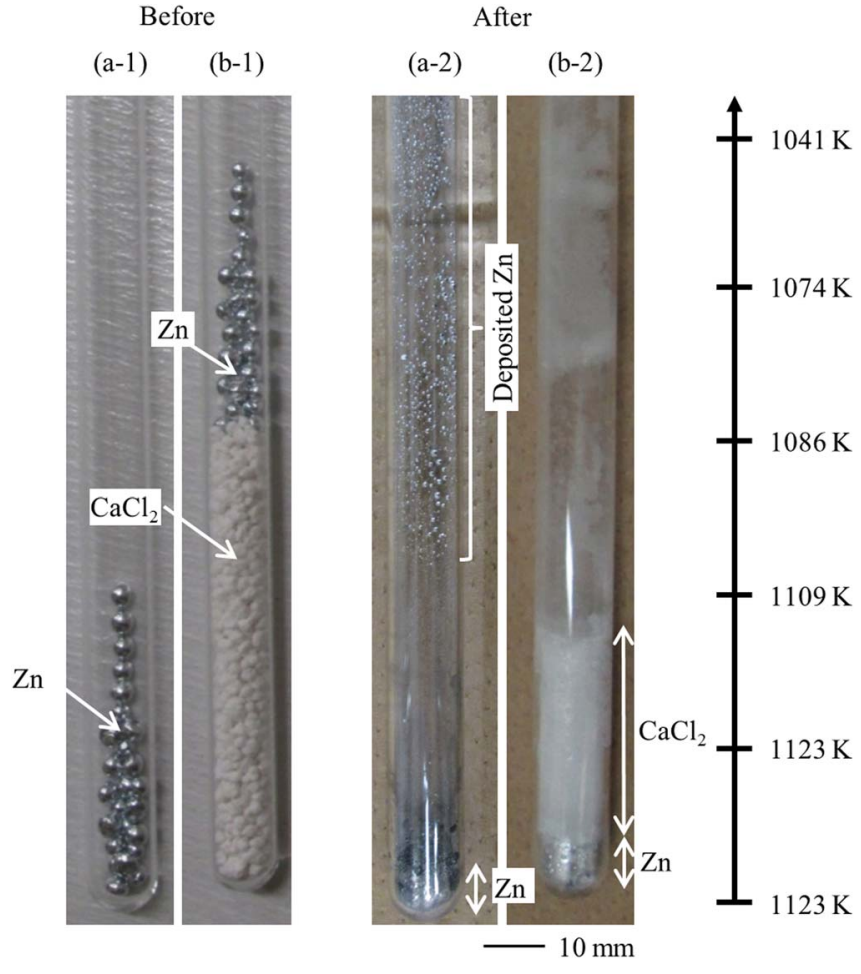

Figure 5. Photographs of the samples (a-1),(b-1) before and (a-2),(b-2) after the evaporation experiments. The evaporation experiments were performed (a-1),(a-2) without and (b-1),(b-2) with immersion in molten $\mathrm{CaCl}_{2}$ at $1123 \mathrm{~K}$ for $6 \mathrm{~h}$.

SSA-S grade, o.d. $13 \mathrm{~mm}$, i.d. $9 \mathrm{~mm}$ ) with an open window $10 \mathrm{~mm}$ $\times 20 \mathrm{~mm}$ in size on the side. A Mo wire (Nilaco Corp., dia. $1.0 \mathrm{~mm}$, 99.95\%) threaded into an alumina insulating tube (Nikkato Corp., SSA-S grade, o.d. $2.0 \mathrm{~mm}$, i.d. $1.0 \mathrm{~mm}$ ) was used for an electric lead. Purified $\mathrm{SiO}_{2}$ grains (Taiheiyo Cement Corp., dia. $<0.1 \mathrm{~mm}, 0.30 \mathrm{~g}$ ) were placed above the $\mathrm{Zn}$ grains. The densities of liquid $\mathrm{Zn}$, solid $\mathrm{SiO}_{2}$, and molten $\mathrm{CaCl}_{2}$ are $5.9 \mathrm{~g} \mathrm{~cm}^{-3}, 622.2 \mathrm{~g} \mathrm{~cm}^{-3}$, and $2.05 \mathrm{~g} \mathrm{~cm}^{-363}$ at $1123 \mathrm{~K}$, respectively. The counter electrode was a graphite rod (Tokai

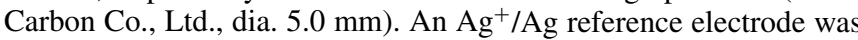
used. ${ }^{18}$ The potential was calibrated using the $\mathrm{Ca}^{2+} / \mathrm{Ca}$ redox potential measured by electrodepositing $\mathrm{Ca}$ metal on a Mo wire electrode (Nilaco Corp., dia. $1.0 \mathrm{~mm}, 99.95 \%) .{ }^{18}$ In the cyclic voltammetry tests, in situ IR compensation using an electrochemical measurement system was performed with a compensation ratio of $95 \%$, which was the highest value in the range that did not cause potential instability. After potentiostatic electrolysis, the sample was recovered from the cell within $1 \mathrm{~min}$ and allowed to cool to room temperature by ra- diative cooling. The samples remaining in the alumina tube were cut into halves and polished with emery paper of descending degrees of roughness, specifically, \#240, 400, 600, 1000, and 2000, and finally with a buffing compound (Buehler, Micro Polish II, $0.3 \mu \mathrm{m}$ ). The analysis was conducted using scanning electron microscopy (SEM; Keyence Corp., VE-8800) and energy-dispersive X-ray spectroscopy (EDX; AMETEK, EDAX Genesis APEX2).

Alloying reaction between solid Si and liquid $\mathrm{Zn}$.-Z Zn granules (330 or 660 g, Wako Pure Chemical Industries, Ltd., grains) were charged into $210 \mathrm{~g}$ of molten $\mathrm{CaCl}_{2}$ to prepare a $\mathrm{Zn}$ pool in a graphite crucible (Toyo Tanso Co., Ltd., IG-110 grade, o.d. $90 \mathrm{~mm}$, i.d. $80 \mathrm{~mm}$, height $120 \mathrm{~mm}$ ) in a dry Ar atmosphere at $1123 \mathrm{~K}$. Single-crystal Si plates [SUMCO Corp., $6 \mathrm{~mm} \times 35 \mathrm{~mm}$, thickness $0.5 \mathrm{~mm}$, n-type, (100) plane, resistivity $1-10 \Omega \mathrm{cm}$ ] or Si prismatic rods (Furuuchi Chemical Corp., $4 \mathrm{~mm} \times 4 \mathrm{~mm}$, height $30 \mathrm{~mm}$ ) attached to a $\mathrm{Ni}$ wire (Ryoko Sangyo Co., Ltd., $>99 \%$, dia. $1.0 \mathrm{~mm}$ ) and mullite tubes (Nikkato Corp., HB-grade, o.d. $6 \mathrm{~mm}$, i.d. $4 \mathrm{~mm}$, length $500 \mathrm{~mm}$ ) were immersed in the $\mathrm{Zn}$ pool for 2-60 s. Round Si rods (Furuuchi Chemical Corp., dia. $6 \mathrm{~mm}$, length $50 \mathrm{~mm}$ ) affixed to a stainless steel tube (SUS304, o.d. $12.0 \mathrm{~mm}$, i.d. $8.0 \mathrm{~mm}$, length $500 \mathrm{~mm}$ ) by a ceramic bond were also used for the measurements. For some experiments, $\mathrm{Si}$ lumps were added to the liquid $\mathrm{Zn}$ pool to prepare $\mathrm{Si}-\mathrm{Zn}$ alloys. $\mathrm{Si}$ samples were immersed in the $\mathrm{Zn}$ pool or $\mathrm{Si}-\mathrm{Zn}$ pool for a fixed duration and then pulled out and cooled at room temperature. After the adhered salt was washed away with water, the thickness or diameter of the Si specimens before and after immersion was measured by a micrometer.

\section{Results and Discussion}

Evaporation of $\mathbf{Z n}$.- Since the vapor pressure of $\mathrm{Zn}$ at the electrolysis temperature of $1123 \mathrm{~K}$ is rather high $(0.54 \mathrm{~atm}),{ }^{52}$ one may assume that metallic $\mathrm{Zn}$ cannot be used as a liquid electrode because of immediate evaporation at temperatures close to its boiling point. On the other hand, the suppression of $\mathrm{Zn}$ evaporation in molten salt is well expected by the analogy that the evaporation rate of water in a test tube is significantly suppressed when the surface of water is covered by oil. Thus, the evaporation behavior of $\mathrm{Zn}$ in molten $\mathrm{CaCl}_{2}$ was investigated before the electrochemical experiments.

Figure 5 shows photographs of the samples before and after the evaporation experiments at $1123 \mathrm{~K}$ for $6 \mathrm{~h}$. When only $\mathrm{Zn}$ metal was placed at the bottom of the tube maintained in Ar atmosphere, a considerable quantity of $\mathrm{Zn}$ deposits was observed on the upper side of the inner part of the tube, where the temperature was lower than 1100 $\mathrm{K}$ (Figure 5a2). These deposits result from evaporation and transport from the liquid $\mathrm{Zn}$ through the gas phase. On the other hand, in the presence of a molten $\mathrm{CaCl}_{2}$ layer of 5.4-5.6 g, solidified $\mathrm{CaCl}_{2}$ and $\mathrm{Zn}$ layers were observed, and no deposit was formed in the upper part, as shown in Figure 5b2. The stacking sequence of these layers $\left(\mathrm{CaCl}_{2}\right.$ above $\mathrm{Zn}$ ) is determined by their densities, and the layer thickness is

Table II. Weight of $\mathrm{Zn}$ samples after evaporation experiments at $1123 \mathrm{~K}$.

\begin{tabular}{|c|c|c|c|c|c|c|}
\hline & & & \multicolumn{4}{|c|}{ Weight of $\mathrm{Zn}$} \\
\hline Time, $t / \mathrm{h}$ & Thickness of $\mathrm{CaCl}_{2}$ layer, $l_{\mathrm{CaCl}_{2}} / \mathrm{mm}$ & Surface area, $A / \mathrm{cm}^{2}$ & Before, $W_{\text {bef }} / \mathrm{g}$ & After, $W_{\text {aft }} / \mathrm{g}$ & $\operatorname{Loss}^{\mathrm{a}}, W_{\text {loss }} / \mathrm{g}$ & $\operatorname{Loss}^{\mathrm{b}}, w_{\text {loss }} / \mathrm{g} \mathrm{cm}^{-2}$ \\
\hline 0.25 & 0 & 0.866 & 5.5322 & 5.2184 & $3.14 \times 10^{-1}$ & 0.362 \\
\hline 0.25 & 31 & & 5.5119 & 5.5026 & $9.30 \times 10^{-3}$ & 0.0107 \\
\hline 6 & 0 & & 5.4502 & 4.3979 & 1.05 & 1.22 \\
\hline 6 & 31 & & 5.6016 & 5.5730 & $2.86 \times 10^{-2}$ & 0.0330 \\
\hline 6 & 47 & & 5.4916 & 5.4672 & $2.44 \times 10^{-2}$ & 0.0282 \\
\hline 24 & 0 & & 5.5781 & 1.6440 & 3.93 & 4.54 \\
\hline 24 & 31 & & 5.5310 & 5.4401 & $9.09 \times 10^{-2}$ & 0.105 \\
\hline 24 & 47 & & 5.4688 & 5.4141 & $5.47 \times 10^{-2}$ & 0.0632 \\
\hline
\end{tabular}



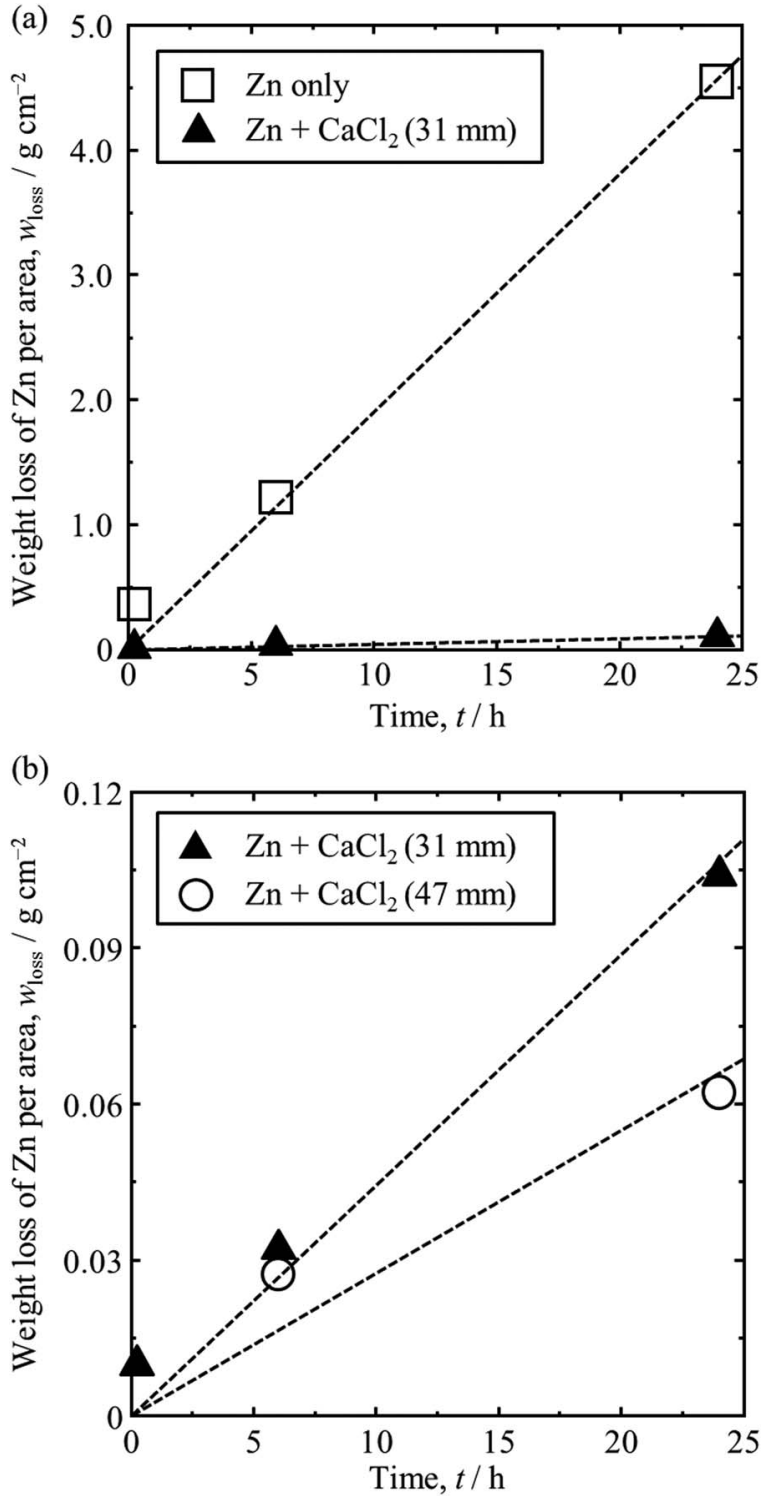

Figure 6. Weight loss of $\mathrm{Zn}$ per area at $1123 \mathrm{~K}$. (a) Plots with and without immersion of $\mathrm{Zn}$ sample in molten $\mathrm{CaCl}_{2}$. (b) Weight loss versus time for $\mathrm{CaCl}_{2}$ layer thicknesses of 31 and $47 \mathrm{~mm}$.

the same as that calculated ( $\left.\mathrm{Zn}: 10 \mathrm{~mm}, \mathrm{CaCl}_{2}: 31 \mathrm{~mm}\right)$. The weight loss of $\mathrm{Zn}$ metal in the experiments with and without the presence of molten $\mathrm{CaCl}_{2}$ over liquid $\mathrm{Zn}$ is summarized in Table II and plotted in Figure 6a versus the reaction time. The graph clearly shows that evaporation was significantly suppressed by the presence of the molten salt layer above the liquid $\mathrm{Zn}$ metal. In both cases, the weight of the $\mathrm{Zn}$ metal decreased almost linearly with time. The evaporation rate, defined as the slope of the plot is $1.90 \times 10^{-1} \mathrm{~g} \mathrm{~cm}^{-2} \mathrm{~h}^{-1}$ when the $\mathrm{Zn}$ metal was evaporated in the absence of $\mathrm{CaCl}_{2}$. The rate decreases significantly to $4.45 \times 10^{-3} \mathrm{~g} \mathrm{~cm}^{-2} \mathrm{~h}^{-1}$ (0.023 times) in the presence of the molten salt, which corresponds to an evaporation rate of 0.18 $\mathrm{mm}$ day $^{-1}$. Thus, the evaporation of $\mathrm{Zn}$ metal covered with molten $\mathrm{CaCl}_{2}$ is found to be negligibly small when it is used as a cathode in the electrolysis process, despite the high vapor pressure of $\mathrm{Zn}$.

In spite of the slowed kinetics, a small evaporation of $\mathrm{Zn}$ was observed in this study which is different from the case of water covered with an immiscible oil layer. The different kinetics results from solubility of the species in the covered layer. The concentration of $\mathrm{Zn}$ in the 31-mm-thick molten $\mathrm{CaCl}_{2}$ after reaction for $24 \mathrm{~h}$ was determined as $0.91 \mathrm{wt} \%$ by ICP-AES. Thus, $\mathrm{Zn}$ metal is thought to first dissolve

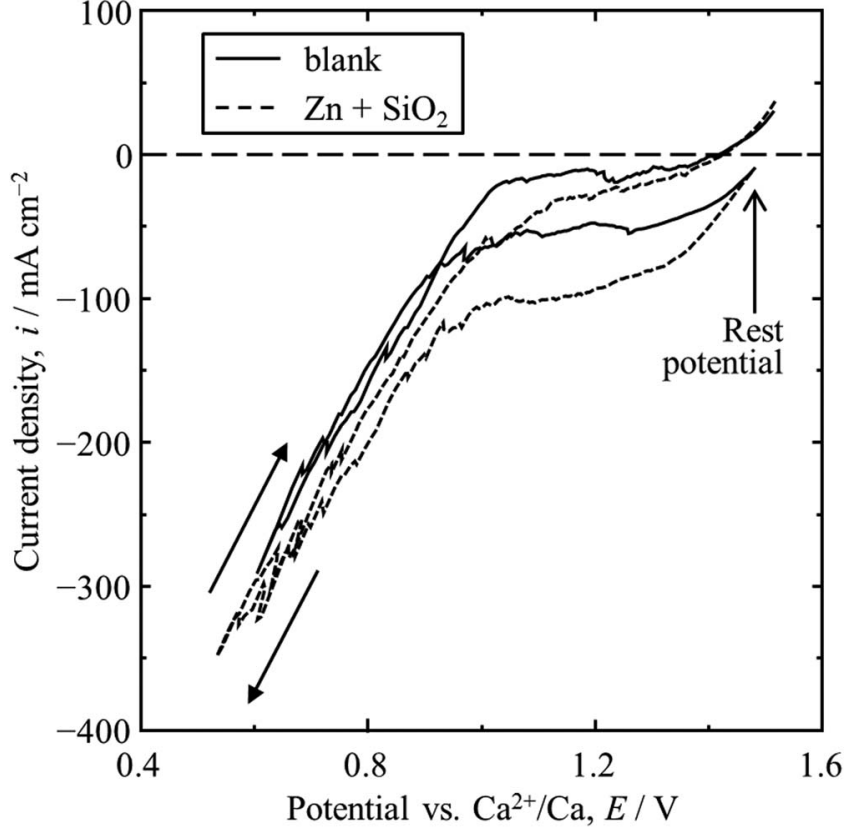

Figure 7. Cyclic voltammograms for liquid $\mathrm{Zn}$ electrodes in molten $\mathrm{CaCl}_{2}$ at $1123 \mathrm{~K}$. Scan rate: $0.2 \mathrm{~V} \mathrm{~s}^{-1}$.

into the molten salt and then evaporate at the interface between the gas and the molten salt after transport in the melt. To investigate the effect of diffusion distance of the dissolved $\mathrm{Zn}$ in molten $\mathrm{CaCl}_{2}$ on the evaporation rate, experiments were carried out with different thicknesses of molten salt layer. Figure $6 \mathrm{~b}$ compares the evaporation behavior at different thicknesses of the molten $\mathrm{CaCl}_{2}$ layer. The evaporation rates for thicknesses of 31 and $47 \mathrm{~mm}$ are $4.45 \times 10^{-3}$ and $2.75 \times 10^{-3}$ $\mathrm{g} \mathrm{cm}^{-2} \mathrm{~h}^{-1}$, respectively. Obviously, the rate of weight loss varies inversely with the thickness of the $\mathrm{CaCl}_{2}$ layer. Thus, diffusion in the molten salt is likely the rate-determining step.

Electrochemical behavior.-Figure 7 shows the cyclic voltammograms of a liquid $\mathrm{Zn}$ electrode with and without $\mathrm{SiO}_{2}$ granules. The solid curve for $\mathrm{Zn}$ metal without an addition of $\mathrm{SiO}_{2}$ granules indicates a negative current around $50 \mathrm{~mA} \mathrm{~cm}{ }^{-2}$ from the rest potential $(1.48$ $\mathrm{V}$ vs. $\mathrm{Ca}^{2+} / \mathrm{Ca}$ ) and a sharp current increase at $0.9 \mathrm{~V}$. Because $\mathrm{Ca}$ and $\mathrm{Zn}$ form a liquid phase over the entire composition range at $1123 \mathrm{~K}^{64}$ this current is attributed to the formation of liquid $\mathrm{Ca}-\mathrm{Zn}$ alloy. The potential of $0.9 \mathrm{~V} \mathrm{vs} \mathrm{Ca}^{2+} / \mathrm{Ca}$ corresponds to the $\mathrm{Ca}$ mole fraction of $1.6 \times 10^{-6}$ in liquid $\mathrm{Ca}-\mathrm{Zn}$ alloy calculated from Henry's law and the reported activity coefficient of $\mathrm{Ca}$ at $1073 \mathrm{~K}\left(2.15 \times 10^{-3}\right){ }^{65}$ To confirm the reaction, the $\mathrm{Zn}$ electrode was galvanostatically electrolyzed at $-1.06 \mathrm{~A} \mathrm{~cm}^{-2}$ for $30 \mathrm{~min}$. The open-circuit potential immediately after electrolysis was $0.35 \mathrm{~V}$. When the sample was analyzed by EDX, the composition of the surface zone was determined to be 90 at $\% \mathrm{Zn}-$ 10 at $\% \mathrm{Ca}$. These values agree with those calculated from the reported activity coefficient of $\mathrm{Ca}{ }^{65}$ Incidentally, the $\mathrm{Ca}$ content was below the detection limit of EDX in the samples obtained by potentiostatic electrolysis at $0.90 \mathrm{~V}$, which is explained by the fact that less electricity is used compared to the case of galvanostatic electrolysis. From the above results, the reduction current observed at values more negative than $0.9 \mathrm{~V}$ is attributed to the formation of liquid $\mathrm{Ca}-\mathrm{Zn}$ alloys.

$$
\mathrm{Zn}(l)+y \mathrm{Ca}^{2+}+2 y \mathrm{e}^{-} \rightarrow \mathrm{ZnCa}_{y}(l)
$$

The broken curve in Figure 7 shows the voltammogram for the $\mathrm{Zn}$ electrode after the addition of $\mathrm{SiO}_{2}$. Although the rest potential is almost identical to that before the addition of $\mathrm{SiO}_{2}$, larger cathodic currents of $100 \mathrm{~mA} \mathrm{~cm}^{-2}$ are observed during the scan in the negative direction. Thus, the increased current suggests the reduction of $\mathrm{SiO}_{2}$ 
(a)

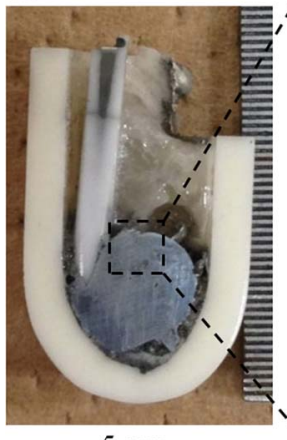

(b)

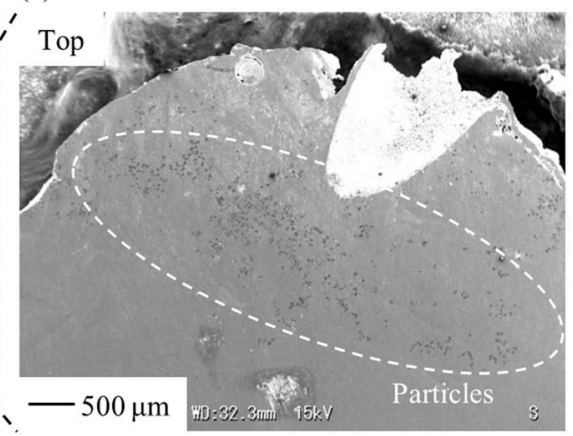

(c)

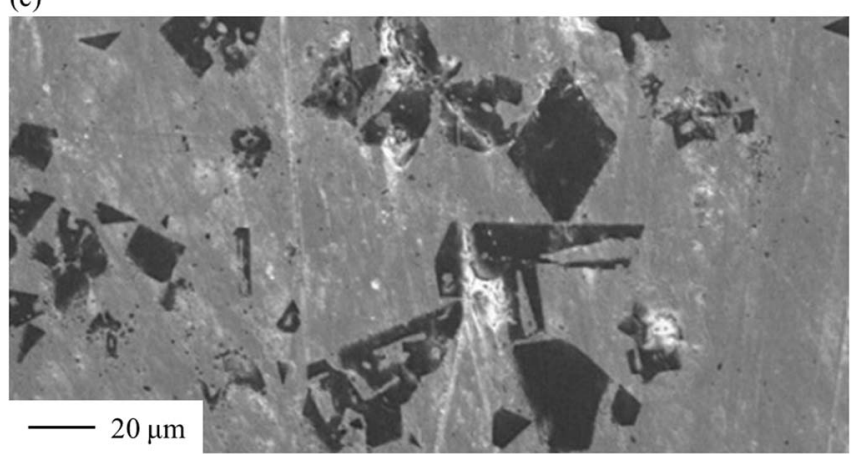

Figure 8. (a) Photograph and (b),(c) cross-sectional SEM images of the sample obtained by potentiostatic electrolysis of liquid $\mathrm{Zn}$ electrode with $\mathrm{SiO}_{2}$ granules at $0.90 \mathrm{~V}$ for $60 \mathrm{~min}$ in molten $\mathrm{CaCl}_{2}$ at $1123 \mathrm{~K}$.

to form liquid $\mathrm{Si}-\mathrm{Zn}$ alloy between 0.9 and $1.45 \mathrm{~V}$.

$$
\mathrm{SiO}_{2}(s)+\mathrm{Zn}(l)+4 \mathrm{e}^{-} \rightarrow \mathrm{Si}-\mathrm{Zn}(l)+2 \mathrm{O}^{2-}
$$

To proceed a direct electrolytic reduction of insulating solid $\mathrm{SiO}_{2}$, the use of a current collector is necessary for electron supply. Here, the onset potential of $\mathrm{SiO}_{2}$ reduction on the liquid $\mathrm{Zn}$ cathode $(1.45 \mathrm{~V})$ is more positive than that on a solid current collector such as a Mo electrode $(1.25 \mathrm{~V}),{ }^{17}$ which is explained by the lower activity of $\mathrm{Si}$ in the $\mathrm{Zn}-\mathrm{Si}$ alloy.

On the basis of the voltammertic results, potentiostatic electrolysis was conducted for a liquid $\mathrm{Zn}$ electrode after $\mathrm{SiO}_{2}$ granules with a diameter of $0.1 \mathrm{~mm}$ were added at $0.90 \mathrm{~V}$ for $60 \mathrm{~min}$ in molten $\mathrm{CaCl}_{2}$ at $1123 \mathrm{~K}$. The sample was observed after cross-sectioning in the vertical direction. Figures $8 \mathrm{a}$ and $8 \mathrm{~b}$ show cross-sectional optical and SEM images, respectively, of the sample after electrolysis. The precipitated grains are observed only on the upper part of the $\mathrm{Zn}$ electrode. According to EDX analysis for the particles shown in the magnified SEM image in Figure 8c, Si is detected to be $100 \mathrm{wt} \%$ and other elements are below their detection limits. Thus, the deposition of Si particles with sizes of $2-30 \mu \mathrm{m}$ in the $\mathrm{Zn}$ matrix is confirmed. According to the $\mathrm{Si}-\mathrm{Zn}$ phase diagram, ${ }^{54}$ the solubility of $\mathrm{Si}$ in liquid $\mathrm{Zn}$ metal is 6.0 at\% at $1123 \mathrm{~K}$, and it becomes negligibly small in solid $\mathrm{Zn}$ at room temperature. Thus, it is reasonable to conclude that $\mathrm{SiO}_{2}$ was electrochemically reduced to form liquid $\mathrm{Si}-\mathrm{Zn}$ alloy [Reaction 5] and that Si particles were precipitated during the cooling process. The precipitated Si particles are observed only in the upper part because they floated and aggregated in the liquid phase owing to their lower density.

The anodic reaction is an evolution of $\mathrm{CO}_{2}$ gas because consumption of the graphite rod counter electrode was observed after the experiment. Since the amount of recovered $\mathrm{Si}$ was small, which is mainly due to the recovery loss during the $\mathrm{HCl}$ leaching, the current efficiency is not discussed in this study. In the case of direct electrolytic reduction of solid $\mathrm{SiO}_{2}$ to solid $\mathrm{Si}$ in molten $\mathrm{CaCl}_{2}$, the current efficiencies were already reported to be $90 \%$ for $\mathrm{SiO}_{2}$ plates ${ }^{17}$ and $70.3-78.5 \%$ for $\mathrm{SiO}_{2}$ granules. ${ }^{24}$ Current efficiency for the production of liquid $\mathrm{Si}-\mathrm{Zn}$ alloy might be also influenced by the side reaction of liquid $\mathrm{Ca}-\mathrm{Zn}$ alloy formation.

Alloying reaction between solid $\mathrm{Si}$ and liquid $\mathrm{Zn}$.-Figure 9 shows photographs taken before and after the alloying experiments at $1123 \mathrm{~K}$ for different immersion times. After the experiments, $\mathrm{Zn}$ was not found on the surface of the recovered Si plate by either visual observation or EDX analysis. The liquid alloy formed at high temperature was probably removed as the sample was pulled out through the molten $\mathrm{CaCl}_{2}$ layer. The photographs in Figure 9 clearly show a decrease in the plate thickness due to dissolution of $\mathrm{Si}$, even for the sample immersed in $\mathrm{Zn}$ for $2 \mathrm{~s}$. For the Si plate reacted for 60 $\mathrm{s}$, the immersed part of the Si plate disappeared completely. Because the alloying reaction proceeds on both sides of the Si plate, the decrease in thickness was evaluated as the value for one side; the results are listed in Table III. As shown in Figure 10, the thickness of the plate decreases linearly with increasing immersion time, and the alloying rate is determined to be $4.56 \mu \mathrm{m} \mathrm{s}^{-1}$ from the slope of the plots.

Similar measurements were made for $\mathrm{Si}-\mathrm{Zn}$ alloy pools with different $\mathrm{Si}$ concentrations, and the results are summarized in Table III and Figure 10. The alloy formation rate decreases with increasing Si concentration in the liquid alloy. The alloy formation rate $\left(v_{\text {alloy }}\right)$ is plotted in Figure 11 against the Si concentration $\left(c_{\mathrm{Si}}\right)$ in the alloy. A (a)

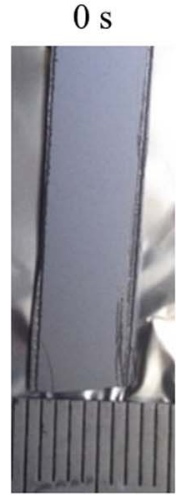

(b) $2 \mathrm{~s}$

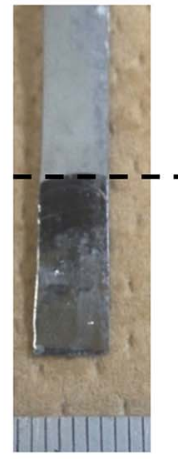

(c) $20 \mathrm{~s}$

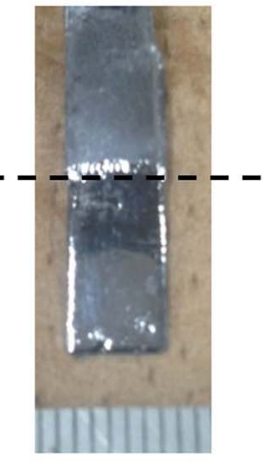

(d)

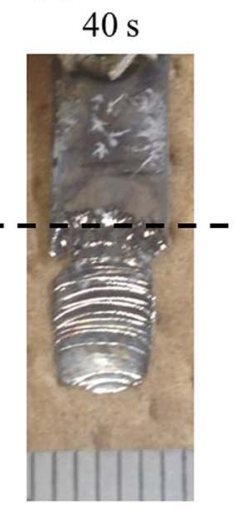

(e)
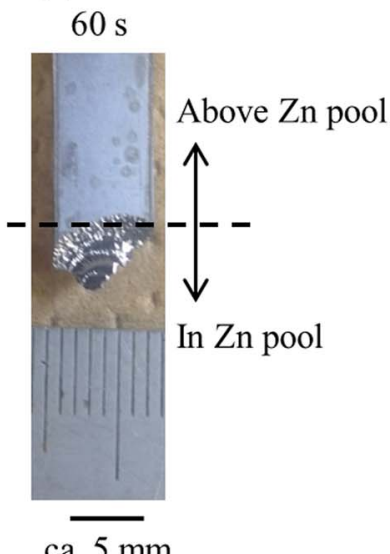

Figure 9. Photographs of Si plates (a) before and after immersion in the Zn pool at $1123 \mathrm{~K}$ for (b) $2 \mathrm{~s}$, (c) $20 \mathrm{~s}$, (d) $40 \mathrm{~s}$, and (e) $60 \mathrm{~s}$. 
Table III. Thickness of Si plate or diameter of $\mathrm{Si}$ rod and alloy formation rate in $\mathrm{Zn}$ pool at each Si concentration at $1123 \mathrm{~K}$.

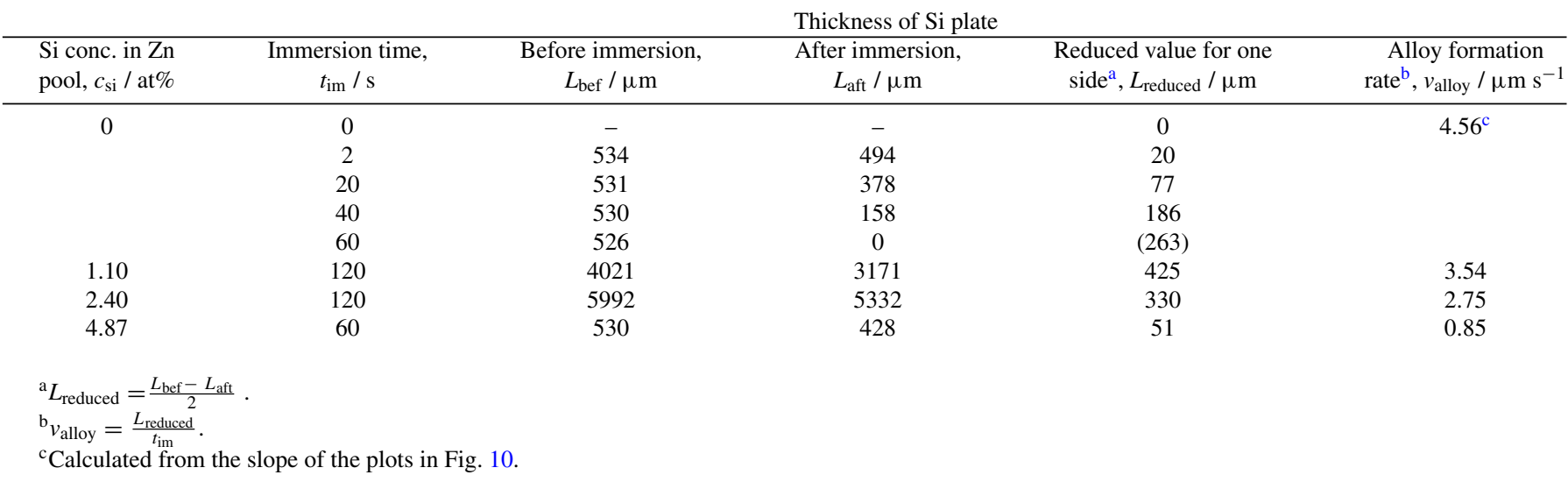

linear relationship between $v_{\text {alloy }}$ and $c_{\mathrm{Si}}$ is clearly observed.

$$
\begin{gathered}
v_{\text {alloy }}=-0.747 c_{\mathrm{Si}}+4.49 \\
=0.747\left(6.0-c_{\mathrm{Si}}\right)
\end{gathered}
$$

Extrapolation indicates that the alloy formation rate becomes zero at $6.0 \mathrm{at} \% \mathrm{Si}$, which is consistent with the solubility in liquid $\mathrm{Si}-\mathrm{Zn}$ alloy. ${ }^{54}$ This fact suggests that the alloying reaction is controlled by diffusion of $\mathrm{Si}$ atoms in the diffusion layer between solid $\mathrm{Si}$ and liquid $\mathrm{Zn}$.

The linearity of the plots for 0 at $\%$-Si in Figure 10a is attributed to rapid diffusion of $\mathrm{Si}$ in liquid $\mathrm{Zn}$, which is expected to be on the order of $10^{-4} \mathrm{~cm}^{2} \mathrm{~s}^{-1}$ from the reported diffusion coefficients of $\mathrm{Fe}$ [(1-5) $\left.\times 10^{-4} \mathrm{~cm}^{2} \mathrm{~s}^{-166}\right]$ and $\mathrm{Al}\left(1.1 \times 10^{-4} \mathrm{~cm}^{2} \mathrm{~s}^{-167}\right)$ in liquid $\mathrm{Zn}$ at $1123 \mathrm{~K}$. The parabolic growth of the diffusion layer thickness is complete at only $1.05 \mathrm{~s}$, as calculated from the alloy formation rate of 4.56 $\mu \mathrm{m} \mathrm{s}^{-1}$ and the estimated diffusion coefficient of $1 \times 10^{-4} \mathrm{~cm}^{2} \mathrm{~s}^{-1}$. This behavior results in the positive deviation of the plot for reaction for $2 \mathrm{~s}$.

To estimate the rate-determining step of electrochemical reduction of $\mathrm{SiO}_{2}$ using a liquid $\mathrm{Zn}$ electrode, the alloying rate is compared with the reaction rate in the other steps involved in the reaction. According to our previous studies, the electrochemical reduction rates

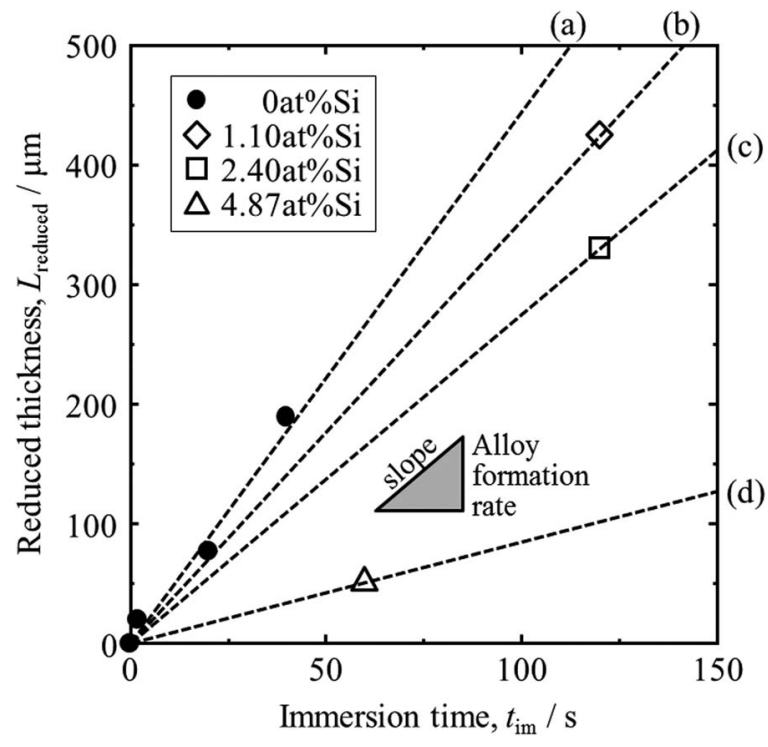

Figure 10. Reduction in thickness of Si plate and rod after immersion at 1123 K. Si concentration in $\mathrm{Zn}$ pool was (a) 0 at\%, (b) 1.10 at\%, (c) 2.40 at\%, and (d) 4.87 at $\%$. are estimated from the results at a reaction time of $300 \mathrm{~s}$ in molten $\mathrm{CaCl}_{2}$ at $1123 \mathrm{~K}$ as $2.1 \mu \mathrm{m} \mathrm{s}^{-119}$ and $0.27 \mu \mathrm{m} \mathrm{s}^{-117}$ for the surface and inner directions of solid $\mathrm{SiO}_{2}$, respectively. Furthermore, the reaction for the inner direction becomes slower with increasing electrolysis time because the diffusion length for the $\mathrm{O}^{2-}$ ions in the porous $\mathrm{Si}$ layer becomes longer. These rates are schematically compared in Figure 12. Obviously, the alloy formation rate is higher than the reduction rates. This comparison suggests rapid removal of the porous Si layer formed at the outermost surface of the $\mathrm{SiO}_{2}$, in the same analogy with the removal of Nd-Fe liquid alloy from the surface of an iron cathode in rare earth electrometallurgy. ${ }^{68}$ The removal of the surface layer retarding the diffusion of $\mathrm{O}^{2-}$ ions would lead to continuation of the fast reaction, which was confirmed to be equivalent to $0.7 \mathrm{~A} \mathrm{~cm}^{-2}$ in the Hall-Héroult process using molten salt electrolysis. ${ }^{21,22}$

\section{Conclusions}

An electrolytic production process for SOG-Si using liquid $\mathrm{Si}-\mathrm{Zn}$ alloy in molten $\mathrm{CaCl}_{2}$ was proposed. The presence of the molten salt above a liquid $\mathrm{Zn}$ layer significantly suppressed evaporation of $\mathrm{Zn}$. The evaporation rate at $1123 \mathrm{~K}$ was $0.18 \mathrm{~mm} \mathrm{day}^{-1}$, which is slow enough that a liquid $\mathrm{Zn}$ cathode can be used. The reduction of $\mathrm{SiO}_{2}$

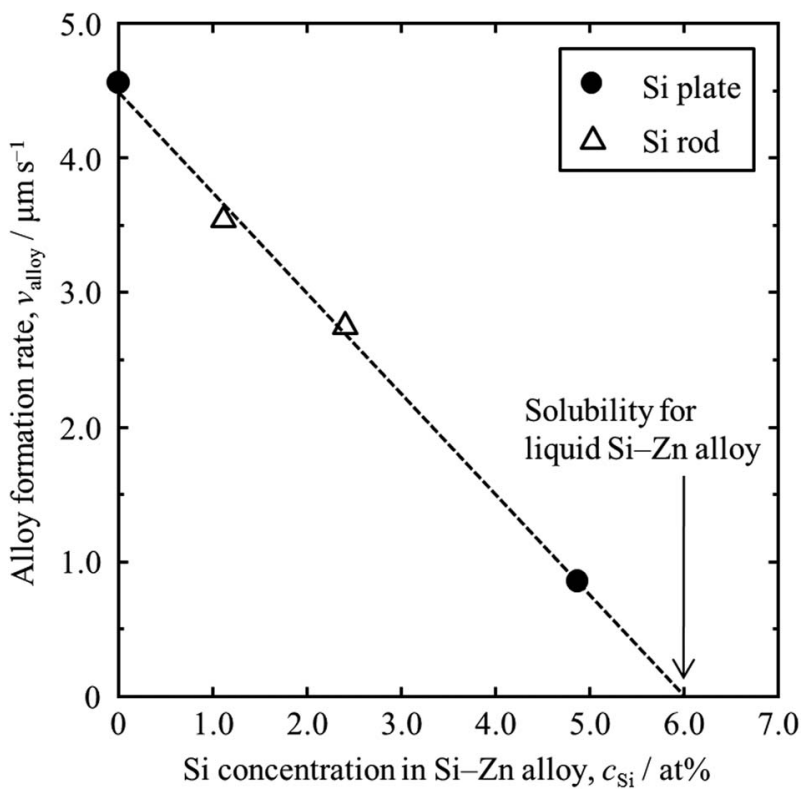

Figure 11. Dependence of alloy formation rate on Si concentration in liquid $\mathrm{Si}-\mathrm{Zn}$ alloy at $1123 \mathrm{~K}$ 


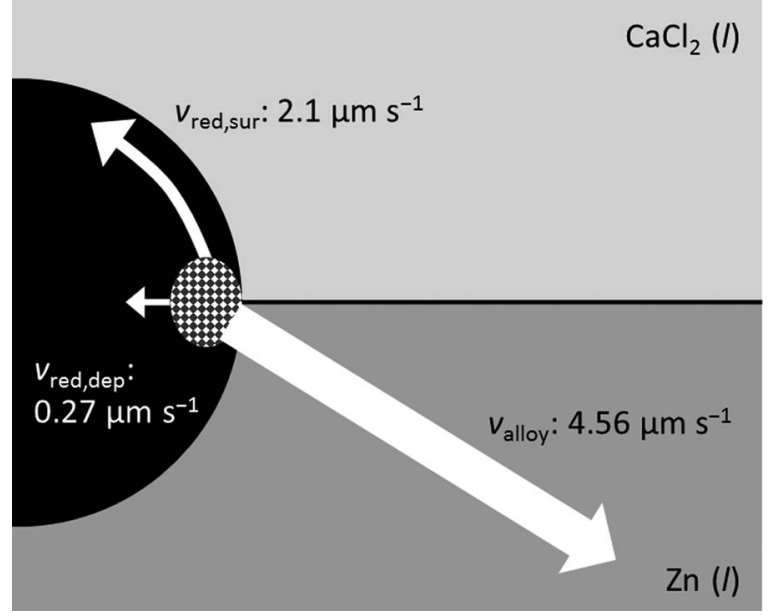

Figure 12. Conceptual drawing of reduction rate of $\mathrm{SiO}_{2}$ and formation rate of liquid $\mathrm{Si}-\mathrm{Zn}$ alloy in molten $\mathrm{CaCl}_{2}$ at $1123 \mathrm{~K}$.

granules on the $\mathrm{Zn}$ cathode to form liquid $\mathrm{Si}-\mathrm{Zn}$ alloy was suggested to proceed from $1.45 \mathrm{~V}$ vs. $\mathrm{Ca}^{2+} / \mathrm{Ca}$ and confirmed at $0.9 \mathrm{~V}$. The alloy formation rate of solid $\mathrm{Si}$ and liquid $\mathrm{Zn}$ was measured to be $4.56 \mu \mathrm{m}$ $\mathrm{s}^{-1}$ at $1123 \mathrm{~K}$, which indicates the potential of rapid reduction of $\mathrm{SiO}_{2}$.

\section{Acknowledgments}

This study was partially supported by Core Research for Evolutionary Science and Technology (CREST) from the Japan Science and Technology Agency (JST); Grant-in-Aid for Scientific Research A, grant Number 16H02410, from the Japan Society for the Promotion of Science (JSPS); The Japan Prize Foundation; and the Kato Foundation for Promotion of Science. The purified $\mathrm{SiO}_{2}$ granules were supplied by Taiheiyo Cement Corporation.

\section{References}

1. Photovoltaic Market 2014, RTS Corp., Tokyo, Japan, 2014. [in Japanese].

2. Rare Metal News, on Aug. 24, 2014, Arumu Publishing Co., Tokyo, Japan. [in Japanese].

3. H. Schweickert, K. Reuschel, and H. Gutsche, U.S. Pat., US3,011,877 (1961).

4. H. Gutsche, U.S. Pat., US3,042,494 (1962).

5. F. Bischoff, U.S. Pat., US3,146,123 (1964).

6. K. Reuschel and A. Kersting, U.S. Pat., US3,200,009 (1965).

7. K. Yasuda and T. H. Okabe, JOM, 62, 94 (2010).

8. K. Yasuda, K. Morita, and T. H. Okabe, Energy Technology, 2, 141 (2014).

9. G. Bye and B. Ceccaroli, Sol. Energy Mater. Sol. Cells, 130, 634 (2014).

10. T. Nohira, K. Yasuda, and Y. Ito, Nat. Mater., 2, 397 (2003).

11. K. Yasuda, T. Nohira, K. Amezawa, Y. H. Ogata, and Y. Ito, J. Electrochem. Soc., 152, D69 (2005).

12. T. Nohira, Yoyuen Oyobi Koon Kagaku, 54, 95 (2011). [in Japanese].

13. K. Yasuda, T. Nohira, R. Hagiwara, and Y. H. Ogata, Electrochim. Acta, 53, 106 (2007).

14. K. Yasuda, T. Nohira, K. Kobayashi, N. Kani, T. Tsuda, and R. Hagiwara, Energy Technology, 1, 245 (2013).

15. T. Homma, N. Matsuo, X. Yang, K. Yasuda, Y. Fukunaka, and T. Nohira, Electrochim. Acta, 179, 512 (2015)

16. T. Toba, K. Yasuda, T. Nohira, X. Yang, R. Hagiwara, K. Ichitsubo, K. Masuda, and T. Homma, Electrochemistry, 81, 559 (2013).

17. K. Yasuda, T. Nohira, and Y. Ito, J. Phys. Chem. Solids, 66, 443 (2005).

18. K. Yasuda, T. Nohira, R. Hagiwara, and Y. H. Ogata, J. Electrochem. Soc., 154, E95 (2007).

19. K. Yasuda, T. Nohira, K. Takahashi, R. Hagiwara, and Y. H. Ogata, J. Electrochem. Soc., 152, D232 (2005).
20. Y. Nishimura, T. Nohira, K. Yasuda, Y. Fukunaka, and R. Hagiwara, Trans. Mater. Res. Soc. Jpn., 35, 47 (2010).

21. X. Yang, K. Yasuda, T. Nohira, R. Hagiwara, and T. Homma, Metall. Mater. Trans. B, 45B, 1337 (2014)

22. X. Yang, K. Yasuda, T. Nohira, R. Hagiwara, and T. Homma, J. Electrochem. Soc., 161, D3116 (2014).

23. X. Yang, K. Yasuda, T. Nohira, R. Hagiwara, and T. Homma, Metall. Mater. Trans. $B$, 47B, 788 (2016).

24. X. Yang, K. Yasuda, T. Nohira, R. Hagiwara, and T. Homma, Metall. Mater. Trans. $E$, 3E, 145 (2016)

25. X. Jin, P. Gao, D. Wang, X. Hu, and G. Z. Chen, Angew. Chem., 116, 751 (2004).

26. P. C. Pistorius and D. J. Fray, J. S. Afr. Inst. Min. Metall., 106, 31 (2006).

27. W. Xiao, X. Jin, Y. Deng, D. Wang, X. Hu, and G. Z. Chen, ChemPhysChem, 7, 1750 (2006).

28. S. Lee, J. Hur, and C. Seo, J. Ind. Eng. Chem., 14, 651 (2008).

29. W. Xiao, X. Jin, Y. Deng, D. Wang, X. Hu, and G. Z. Chen, J. Electroanal. Chem., 639, 130 (2010).

30. E. Juzeliunas, A. Cox, and D. J. Fray, Electrochem. Comm., 12, 1270 (2010).

31. T. Oishi, M. Watanabe, K. Koyama, M. Tanaka, and K. Saegusa, J. Electrochem. Soc., 158, E93 (2011)

32. E. Ergül, İ. Karakaya, and M. Erdoğan, J. Alloy. Compd., 509, 899 (2011).

33. W. Xiao, X. Wang, H. Yin, H. Zhu, X. Mao, and D. Wang, RSC Advances, 2, 7588 (2012).

34. S. K. Cho, F. F. Fan, and A. J. Bard, Electrochim. Acta, 65, 57 (2012).

35. S. K. Cho, F. F. Fan, and A. J. Bard, Angew. Chem., 124, 12912 (2012)

36. W. Xiao, X. Jin, and G. Z. Chen, J. Mater. Chem. A., 1, 10243 (2013).

37. T. Yoshikawa and K. Morita, Sci. Technol. Adv. Mater, 4, 531 (2003).

38. T. Yoshikawa and K. Morita, CAMP-ISIJ, 17, 875 (2004).

39. T. Yoshikawa and K. Morita, Proc. EPD Congress 2005, TMS, Warrendale, pp. 549, 2005.

40. T. Yoshikawa and K. Morita, J. Cryst. Growth, 311, 776 (2009).

41. T. Yoshikawa and K. Morita, JOM, 64, 946 (2012).

42. J. M. Juneja and T. K. Mukherjee, Hydrometallurgy, 16, 69 (1986).

43. A. M. Mitrašinović and T. A. Utigard, Silicon, 1, 239 (2009).

44. X. Ma, T. Yoshikawa, and K. Morita, J. Alloy. Compd., 529, 12 (2012).

45. X. Ma, T. Yoshikawa, and K. Morita, Sep. Purif. Technol., 125, 264 (2014).

46. L. Hu, Z. Wang, X. Gong, Z. Guo, and H. Zhang, Metall. Mater. Trans. B, 44B, 828 (2013).

47. S. Esfahani and M. Barati, Metals Mater. Int., 17, 823 (2011).

48. S. Esfahani and M. Barati, Metals Mater. Int., 17, 1009 (2011).

49. L. T. Khajavi, K. Morita, T. Yoshikawa, and M. Barati, Metall. Mater. Trans. B, 46B, 615 (2015).

50. Z. Yin, A. Oliazadeh, S. Esfahani, M. Johnston, and M. Barati, Can. Metall. Q., 50, 166 (2011).

51. H. Morito, T. Karahashi, M. Uchikoshi, M. Isshiki, and H. Yamane, Silicon, 4, 121 (2012).

52. M. W. Jr. Chase, C. A. Davies, J. R. Jr. Downey, D. J. Frurip, R. A. McDonald, and A. N. Syverud, NIST-JANAF Thermochemical Tables, 4th ed., J. Phys. Chem. Ref. Data, Monograph No. 9, American Chemical Society and the American Institute of Physics for the National Institute of Standards and Technology, New York, USA, 1998.

53. I. Barin, O. Knacke, and O. Kubaschewski, Thermochemical Properties of Inorganic Substances, Supplement, Springer-Verlag, Berlin, Germany, 1977.

54. R. W. Olesinski and G. J. Abbaschian, J. Phase Equilib., 6, 545 (1985).

55. R. W. Olesinski and G. J. Abbaschian, J. Phase Equilib., 5, 273 (1984).

56. R. W. Olesinski and G. J. Abbaschian, J. Phase Equilib., 5, 271 (1984).

57. J. L. Murray and A. J. McAlister, Bulletin of Alloy Phase Diagrams, 5, 74 (1984).

58. T. Yoshikawa and K. Morita, Yoyuen Oyobi Koon Kagaku, 49, 155 (2006). [in Japanese].

59. F. A. Trumbore, Bell System Tech. J., 39, 205 (1960).

60. M. Maeda, Seisan Kenkyu, Institute of Industrial Science at University of Tokyo, $\mathbf{3 8}$, 425 (1986). [in Japanese].

61. G. J. Kipouros and R. A. Sharma, J. Electrochem. Soc., 137, 3333 (1990).

62. T. R. Hogness, J. Am. Chem. Soc., 43, 1621 (1921).

63. G. J. Janz, J. Phys. Chem. Ref. Data, vol. 17, Supplement No. 2, American Chemical Society and the American Institute of Physics for the National Institute of Standards, New York, USA, 1988, p. 23

64. T. B. Massalski, Binary Alloy Phase Diagrams, ASM International, Materials Park, USA, 1996.

65. J. Delcet and J. J. Egan, Metall. Mater. Trans. B, 9B, 728 (1978).

66. M. Kato and S. Minowa, Tetsu-to-Hagane, 52, 32 (1966).

67. S. Yang, X. Su, J. Wang, F. Yin, N. Y. Tang, Z. Li, and X. Li, Metall. Mater. Trans. A, 42A, 1785 (2011).

68. G. Adachi, Ed., Rare Metal Binran, Maruzen Co., Ltd., Tokyo, Japan, 2011. [in Japanese]. 